УДК 322

ББК 63.3(2)61

\title{
Антирелигиозное воспитание молодежи на юге Западной Сибири во второй половине 1940-х - середине 1960-х гг.*
}

\author{
Н.П. Зиберт, Е.А. Шеринева
}

Алтайский государственный университет (Барнаул, Россия)

\section{Anti-Religious Education of Young People in the South of Western Siberia in the Second Half of the 1940s - Middle-1960s}

N.P. Zibert, E.A. Shershneva

Altai State University (Barnaul, Russia)

Рассматривается специфика антирелигиозной пропаганды в молодежной среде во второй половине 1940-х — середине 1960-х гг. Лояльная конфессиональная политика, реализуемая советским правительством с 1943 г., спровоцировала не только открытие новых храмов на юге Западной Сибири, но и увеличила число людей, переставших скрывать свои религиозные убеждения. Изученные авторами архивные документы свидетельствуют, что особое недовольство партийных органов вызывали участившиеся случаи присутствия детей и молодежи на богослужениях и появление в приходах молодых активных священников. При этом важно отметить неоднозначность проводимой антирелигиозной работы, значительный объем которой был направлен непосредственно на молодое поколение и искоренение религиозных предрассудков в их среде. Мероприятия антирелигиозной направленности, проводимые государственными учреждениями различного уровня, широкая сеть кружков, занимающихся политическим просвещением молодежи, активная пропаганда научных и материалистических знаний сосуществовали с непримиримостью, оскорблением религиозных чувств населения и грубым применением административных методов. При этом важно подчеркнуть широко распространенную бытовую религиозность и конформизм в отношении верующих во всех слоях населения, в том числе и среди лиц, занимающихся антирелигиозной пропагандой.

Ключевые слова: государственно-конфессиональная политика, молодежь, атеистическая пропаганда, советский период истории.

DOI 10.14258/izvasu(2019)5-05
The article deals with the specifics of anti-religious propaganda among young people in the second half of the 1940s - mid 1960s. Loyal religious policy implemented by the Soviet government since 1943, provoked not only the opening of new churches in the region, but also increased the percentage of people no longer hide their religious beliefs. The archival documents studied by the author testify that special discontent of party bodies was caused by the frequent cases of presence of children and youth at divine services and emergence in parishes of young active priests. At the same time, it is important to note the ambiguity of the anti-religious work carried out, a significant amount of which was aimed directly at the younger generation and the eradication of religious prejudices among them. Activities of anti-religious orientation carried out by state institutions at various levels, a wide network of circles engaged in political education of young people, active promotion of scientific and materialistic knowledge coexisted with intransigence, insulting religious feelings of the population and rough application of administrative methods. At the same time, it is important to emphasize the widespread domestic religiosity and conformism towards believers in all segments of the population, including among those engaged in anti-religious propaganda.

Key words: state-confessional policy, young people, atheistic propaganda, Soviet period of history.

\footnotetext{
* Статья подготовлена при финансовой поддержке РНФ «Религия и власть: исторический опыт государственного регулирования деятельности религиозных общин в Западной Сибири и сопредельных районах Казахстана в XIX-XX вв.» (проект №19-18-00023).
} 
Изучение особенностей атеистического воспитания молодежи в СССР является одной из актуальных задач в отечественной исторической науке. При этом рассмотрение специфики антирелигиозной работы с подрастающим поколением в недавнем прошлом позволяет осмыслить происходящий в настоящее время процесс переоценки ценностей молодых людей, понять исторические предпосылки и условия формирования отношения последних к вопросам веры. Вопросы антирелигиозного воспитания молодежи в Советском Союзе в рассматриваемый период освещались в работах А.А. Слезина и М.В. Иошкина $[1,2]$. Отдельные региональные аспекты атеистической пропаганды в молодежной среде частично рассмотрены в исследованиях Л.И. Сосковец, П.К. Дашковского, Н.С. Дворянчиковой [3-5]. При этом следует отметить что, как правило, преобладают работы, отражающие общесоюзные тенденции взаимодействия советских органов власти с молодежью. Концептуального изучения данной темы в рассматриваемом регионе до настоящего времени фактически не проводилось.

Научная новизна данной статьи заключается в том, что в ней были предприняты попытки специального комплексного исследования антирелигиозной работы в молодежной среде на юге Западной Сибири во второй половине 1940-х - середине 1960-х гг., а также введен в научный оборот целый ряд архивных материалов из фондов Государственного архива Алтайского края и Государственного архива Новосибирской области.

Целью исследования является рассмотрение специфики антирелигиозного воспитания молодежи на юге Западной Сибири со второй половины 1940-х до середины 1960-х гг.

С 1943 г. в СССР стали происходить серьезные изменения религиозной политики, коснувшиеся всех религиозных общин в разных регионах страны, в том числе в Алтайском крае и Новосибирской области. С июля 1943 г. управляющим НовосибирскоБарнаульской епархией был назначен архиепископ Варфоломей, приступивший к активному открытию храмов в рассматриваемой епархии [6, с. 25]. С конца 1943 г. стал функционировать Покровский собор Бийска. В течение 1944 г. были зарегистрированы еще три общины: Покровской церкви в Барнауле, Вознесенской (Туруханской) церкви в Новосибирске и Петропавловского собора в Томске [3, с. 57]. В 1945 г. возобновились богослужения в ряде населенных пунктов, в том числе Свято-Дмитриевской церкви в Алейске, Вознесенской церкви с. Шипуново, в Покровской церкви с. Ново-Перуново, Болотнинском молитвенном доме в Новосибирской области. В 1946 г. получили регистрацию Троицкий собор в с. Плешкове Алтайского края, Михаило-Архангельский храм в Рубцовске, а также в селах Колывань и НовоЛуговском Новосибирской области. В 1947 г. открылись церкви в с. Ирмень Новосибирской области, молитвенные дома в Славгороде, в Ново-Тальменке и Петровке Троицкого района Алтайского края [3, с. 59].

Активное открытие приходов привело к увеличению количества совершаемых треб. Так, к 1948 г. увеличилось количество крещений, что было объяснено местными властями ростом рождаемости. При этом наибольшее количество треб совершалось в дни революционных праздников, так как нередко население привязывало важные события своей жизни к государственным праздникам. Так, 7 ноября 1948 г. в Барнауле было совершено 171 крещение детей из 328 регистрируемых в среднем за месяц. В Михайловской церкви Рубцовска было совершено 90 крещений из 210 совершаемых в месяц, а в Успенской церкви Бийска - 65 крещений из 126. Аналогичные тенденции фиксировались и в заключаемых церковных браках [7, л. 123].

Немалую роль в этом сыграла пропаганда, осуществляемая священнослужителями. Так, в Бийске настоятель Лавров распространял религиозное учение среди сельских жителей, уделяя особое внимание детям школьного возраста. Как правило, после церковной службы церковь посещали небольшие группы девочек, учениц старших классов школы. В проводимых с ними беседах содержались элементы религиозного поучения. Отдельно подчеркивалась религиозность классиков русской литературы А.С. Пушкина, М.В. Лермонтова, Н.В. Гоголя и др. Нередко церковь оказывала финансовую помощь отдельным учащимся. Так, ученику 4 класса Бурдину за счет средств Успенской церкви Бийска была куплена скрипка. Помимо этого, церковь оплачивала его обучение в музыкальной школе в размере 100 руб. ежемесячно. Старший брат Бурдина был певчим в церковном хоре. В этом же хоре пел ученик 7 класса, сын члена ВКП(б) [7, л. 122].

Важно отметить случаи посещения храмов учащимися средних и высших учебных заведений перед важными экзаменами. Молодые люди ставили свечи, принимали крещение и заказывали молебны. В течение 1948 г. в Покровской церкви Бийска обряд крещения прошли 15 девушек и 9 юношей в возрасте от 16 до 24 лет. В Михайловской церкви Рубцовска в течение 1948 г. было крещено 36 человек в возрасте от 12 до 16 лет и 11 человек в возрасте от 17 до 20 лет, в Димитриевском храме Алейска - 8 человек в возрасте 16 лет. Священник Успенской церкви Бийска совершил на дому крещение молодой учительницы, а также крестил в здании церкви студента машиностроительного техникума Н. Сергеева. Работа с детьми и молодежью велась также в Покровской церкви Барнаула [7, л. 114, 120, 122]. 
Значительный вклад в дело укрепления церкви вносили выпускники духовных учебных заведений, назначаемые митрополитом Варфоломеем во вновь открываемые приходы [8, л. 9]. Так, молодой священник Вознесенского собора В. Ткаченко, в отличие от священников преклонного возраста, регулярно обращался к прихожанам с проповедями и назидательным словом [9, с. 4]. Этот и подобные факты привели к тому, что выпускники духовных семинарий и академий находились под пристальным вниманием не только церковных иерархов, но и представителей советской власти. В апреле 1952 г. уполномоченным Совета по религиозным культам по Новосибирской области П.Н. Созонёнком было получено инструктивное письмо, рекомендовавшее держать деятельность молодых служителей культа под постоянным наблюдением [9, с. 5]. Впоследствии аналогичные указания держать молодые церковные кадры на особом контроле получил Ф.Т. Воротилов, занявший должность уполномоченного в декабре 1952 г. [8, л. 9].

Нужно подчеркнуть, что в рассматриваемый период основным направлением религиозной политики являлась антирелигиозная работа, развернувшаяся как на общесоюзном, так и на региональном уровнях. 7 июля 1954 г. было выпущено постановление ЦК КПСС «О крупных недостатках в научноатеистической пропаганде и мерах по ее улучшению» [10], предназначенное для улучшения атеистической пропаганды среди населения. На отдел ВЛКСМ возлагалось ведение атеистической пропаганды среди молодежи и распространение в ее среде материалистических знаний. Вследствие этого к 1957 г. в Алтайском крае политическим просвещением молодежи занимались 270 комсомольских кружков, в которых обучалось свыше четырех тысяч молодых людей. Всего в крае было подготовлено три тысячи человек [5, с. 43-51].

В целях атеистического воспитания местными органами власти проводились мероприятия различного уровня. В библиотеках читались публичные лекции, посвященные коммунистическому воспитанию, выходил цикл передач на радио, в газетах публиковался материал по антирелигиозной пропаганде, разъяснялось законодательство о религиозных культах.

Большим уважением пользовались лекции доцентов И.Т. Белимова, Ф.И. Овсянниковой, кандидатов философских наук Л.К. Немира, А.Т. Москаленко и др. $[11$, л. 2]. Научному атеизму были посвящены студенческие и аспирантские исследования. В 1962 г. старший лаборант кафедры политэкономии и философии Алтайского политехнического института Н.Н. Васильева собирала сведения о церквях и религиозных сектах в Алтайском крае, используя их для чтения лекций и проведения семинарских занятий по научному атеизму и философии [12, л. 107]. В Томском государственном университете аспирантом кафедры диалектического и исторического материализма В.Ф. Крестьяниновым велась работа над кандидатской диссертацией «Религиозная секта меннонитов и ее реакционная сущность» $[12$, л. 81], вышедшей в 1964 г. под названием «Реакционная сущность идеологии современного меннонитства и пути ее преодоления» [13].

В октябре 1958 г. ЦК КПСС обязал все советские организации развернуть пропагандистское наступление на «религиозные пережитки». При этом упор был сделан на переубеждение и формирование у населения научного мировоззрения, предпринимались попытки внедрить в повседневную жизнь новую советскую обрядность, заменив ею старые религиозные обряды. Важно подчеркнуть, что данные меры смогли сократить лишь число официальных заявлений и обращений верующих, никак не повлияв на общее количество совершаемых религиозных обрядов [14, л. 17]. Более того, отчеты совета по делам религиозных культов свидетельствуют о неудовлетворительной антирелигиозной работе в большинстве районов Новосибирской области. Указания Н.С. Хрущева о необходимости атеистического воспитания трудящихся, озвученные им на XXII съезде КПСС, выполнялись неудовлетворительно [14, л. 2]. Практически отсутствовало атеистическое воспитание родителей, о чем свидетельствует статистика совершаемых крещений. Так, в Вознесенском кафедральном соборе в 1958 г. было совершено 6582 крещений, в 1959 г. их число выросло до 6727. В церквях Новосибирской области в 1958 г. было продано 50 тыс. крестиков, приобретаемых в основном для новорожденных $[15, \pi .2]$.

Аналогичные тенденции фиксировались по всей стране. Так, несмотря на то, что в течение 1960-1962 гг. в СССР было закрыто 2000 молитвенных домов, количество проводимых религиозных обрядов сократилось всего на 2\% [16].

С целью оградить детей от влияния церкви были запрещены детские церковные кружки, пение детей в церковных хорах и их участие в церковных службах. Тщательно отслеживалось факты посещения церквей детьми $[15$, л. 69]. Так, о факте посещения Успенской церкви Бийска жительницей с. Белокуриха ГрачевойМещеряковой с сыном Геной в сентябре 1960 г. было доложено председателю Смоленского райисполкома И.И. Клюкову [12, л. 69]. В этом же месяце секретарь Бийского городского комитета КПСС В.Г. Козлов получил сведения о посещении данной церкви учеником третьего класса Ваней, сопровождавшим глухую бабушку [12, л. 61].

В августе 1961 г. в Успенской церкви Бийска жительница с. Сетовки (Сычевки) крестила троих сво- 
их сыновей: Гену (14 лет), Гошу (10-12 лет) и Лёню (5 лет) [12, л. 59].

В связи с участившимися случаями крещения ребенка без разрешения родителей пожилыми родственницами женского пола в течение 1961-1962 гг. при районных и городских исполкомах были созданы комиссии общественного контроля, следившие за выполнением законодательства о культах и изучающие контингент лиц, посещающих церковь. Наличие соответствующей квитанции с указанием имени и домашнего адреса обратившегося становилось необходимым условием выполнения любой церковной требы $[17$, л. 6]. Для крещения ребенка, помимо его свидетельства о рождении, необходимо было предоставить паспорта родителей и их письменное согласие на совершение крещения. Родители должны были лично присутствовать при совершении таинства.

Комиссии общественного контроля выявляли молодых людей, интересующихся условиями поступления в семинарии $[17$, л. 2]. Например, в октябре 1963 г. был установлен факт письменного запроса в Москву студентами Алтайского сельскохозяйственного института Е.М. Логиновым и В.М. Сашаровым, интересующимися условиями приема в духовную семинарию на 1964-1965 учебный год $[12$, л. $112,114,116]$. В этом же году поступлением в Московскую духовную семинарию интересовался житель с. Верх-Катунского Алтайского края В.И. Пивоваров [12, л. 116, 118].

В 1960 г. ЦК КПСС были изданы постановления «О задачах партийной пропаганды в современных условиях» и «О мерах по ликвидации нарушений духовенством советского законодательства о культах». При этом служебная переписка Совета по делам религии по Новосибирской области с обкомом КПСС свидетельствует о неудовлетворительной постановке работы по атеистическому воспитанию населения в регионе. Открытый судебный процесс над убийцами пионера Володи Енина $[18, \pi .3]$, используемый партийными организаторами и руководителями Новосибирской области для подавления авторитета Русской православной церкви, не смог уничтожить религиозные настроения среди населения, несмотря на всесоюзную огласку и большое количество обличительных статей в прессе [19, с. 78].
Периодически читаемые лекции антирелигиозной тематики и беседы с населением на атеистические темы не достигали нужного результата, так как верующие игнорировали эти мероприятия. В ходе проверок, проводимых партийным активом с целью установления религиозности населения, было выявлено большое количество домов, в которых имелись иконы [5, с. 43-51]. Аналогичная ситуация наблюдалась и в других регионах. Иконы обнаруживались даже в домах комсомольского актива [1, с. 185]. Причем сами комсомольцы нередко проявляли конформизм к верующим, особенно из числа своих родственников [2, с. 151].

Таким образом, атеистическая работа, проводимая силами партийных, комсомольских и общественных организаций, агрессивная антирелигиозная пропаганда и административное закрытие церквей не привели к полному отмиранию религии и значительному снижению проявлений религиозной жизни среди населения. В то время как открываемые приходы нуждались в молодых священниках, способных продолжить церковное служение, советские органы власти видели в молодежи потенциальных борцов с религиозными предрассудками и опору советского режима. Молодые люди, ставшие с середины 1940-х гг. объектом пристального внимания как церковных иерархов, так и советских органов власти, как правило, хоть и не решались активно и публично отстаивать свою веру, тем не менее не отказывались от своих религиозных убеждений. Такую ситуацию наглядно демонстрировала статистика венчаний и крещений. При этом, несмотря на достаточно широко развитую сеть кружков политического просвещения, антирелигиозная работа зачастую сводилась к периодически читаемым лекциям на атеистическую тематику и запугиванию административными мерами. Важно подчеркнуть, что подобными методами в своей работе пользовались не только работники государственных и партийных аппаратов, но и школьные учителя [4, с. 37-47]. Постоянное оскорбление религиозных чувств, непримиримый и поверхностный уровень проводимой разъяснительной работы приводили к сохранению у молодых людей религиозных убеждений и лишь видимому присутствию у последних научно-атеистического мировоззрения.

\section{Библиографический список}

1. Слезин А.А. Комсомол против религии: метаморфозы 1950-х годов // Исторические, философские, политические и юридические науки, культурология и искусствоведение. Вопросы теории и практики. 2016. №9(71).
2. Иошкин М.В. Комсомольская свадьба в системе атеистических действий на рубеже 1950-1960-х годов // Вопросы современной науки и практики / Университет им. В.И. Вернадского. 2014. №3 (53). 
3. Сосковец Л.И. Религиозные конфессии Западной Сибири в 40-60-е гг. XX в. Томск, 2003.

4. Дашковский П.К., Дворянчикова Н.С. Некоторые особенности положения христианских общин алтайского края в системе государственно-конфессиональных отношений СССР // Религиоведение. 2015. № 1.

5. Дашковский П.К., Дворянчикова Н.С. Региональные аспекты атеистической пропаганды в Алтайском крае в 1953-1964 гг. // Религиоведение. 2015. № 4.

6. Гаврилов В. Новосибирская епархия: История и современность. Новосибирск, 2006.

7. Государственный архив Российской Федерации (ГАРФ). Ф. Р. 6991. Оп. 1. Д. 469.

8. Государственный архив Новосибирской области (ГАНО). Ф. Р. 1418. Оп. 1. Д. 44.

9. Гуляев В. Уполномоченные Совета по делам Русской Православной Церкви в Сибири в 1943-1956 годах. URL: http://history-mda.ru/publ/upolnomochennyie- soveta-po-delam-russkoy-pravoslavnoy-tserkvi-v-sibiri-v1943-1956-godah_4804.html (дата обращения: 04.02.2019).

10. О религии и церкви. М., 1981.

11. ГАНО. Ф. Р. 1418. Оп. 1. Д. 80.

12. Государственный архив Алтайского края (ГААК). Ф. Р. 1692. Оп. 1. Д. 37.

13. Черказьянова И.В. Диссертационные исследования о немецком населении СССР (1920-1980-е гг.) // Вопросы германской истории. 2010.

14. ГАНО. Ф. Р. 1418. Оп. 1. Д. 58.

15. ГАНО. Ф. Р. 1418. Оп. 1. Д. 59.

16. Чарный С.А. Государственная политика в отношении еврейских общин в период «оттепели» (1953-1964) : дис. ... канд. ист. наук. М., 1995.

17. ГААК. Ф. Р. 1692. Оп. 1. Д. 55.

18. ГАНО. Ф. Р. 1418. Оп. 1. Д. 64

19. Выстрел на колокольне // Новосибирская горница. 2000. №1. 